\title{
SCL6A8 mutation in female patient resulting in creatine transporter deficiency
}

\section{Mutacja genu SCL6A8 u dziewczynki wywołująca niedobór transportera kreatyny}

\author{
Zuzanna Lewandowska' (D), Barbara Steinborn' (D), Włodzimierz Borkowski² \\ Elżbieta Chlebowska² (D), Katarzyna Karmelita-Katulska² (D) \\ ${ }^{1}$ Klinika Neurologii Wieku Rozwojowego, Uniwersytet Medyczny im. Karola Marcinkowskiego w Poznaniu \\ ${ }^{2}$ Katedra Radiologii Ogólnej i Neuroradiologii, Uniwersytet Medyczny im. Karola Marcinkowskiego w Poznaniu \\ DOI:10.20966/chn.2018.55.434
}

\section{ABSTRACT}

Cerebral creatine deficiency syndrome is a collective term including different types of disease, all characterised by abnormal creatine level in central nervous system. One of the types, creatine transporter deficiency, is a common cause of X-linked intellectual disability. Typically, it is fully expressed in male patients, however females can also present some symptoms, such as mild intellectual disability, learning difficulties and behavioural problems.

The patient presented in this case report is a 4-year-old girl, diagnosed by genetic testing with creatine transporter deficiency showing a novel mutation in SCL6A8 gene, and by proton magnetic resonance spectroscopy in which she presented a typical abnormality in creatine level in central nervous system. The patient presented speech and motor delay, with mild intellectual disability, behavioural problems and seizures well-controlled by valproic acid.

The prognosis and therapeutic plan in a female patient with CRTR is a big clinical challenge, as there is few data about this mutation being fully expressed in women. The novel therapy methods may be a promising change in further development and symptoms control in patients with CRTR of both sexes.

Keywords: SCL6A8, creatine transporter deficiency, creatine, cerebral creatine deficiency syndrome, intellectual disability, epilepsy, female

\section{STRESCZZENIE}

Zespół mózgowego deficytu kreatyny jest zbiorczym terminem dla określenia różnych podtypów choroby, charakteryzującej się nieprawidłowym poziomem kreatyny w ośrodkowym układzie nerwowym. Jeden z nich, deficyt transportera kreatyny związany z mutacją w genie SCL6A8, jest częstą przyczyną niepełnosprawności intelektualnej związanej z chromosomem X. Typowo mutacja ta ulega pełnej ekspresji u pacjentów płci męskiej, jednakże kobiety również mogą prezentować niektóre z objawów, takie jak niepełnosprawność intelektualna w stopniu lekkim, problemy z uczeniem się i zaburzenia zachowania. Pacjent przedstawiony w poniższym opisie przypadku to 4-letnia dziewczynka ze zdiagnozowanym deficytem transportera kreatyny. U dziewczynki przeprowadzono diagnostykę genetyczną, w której zaobserwowano nieopisaną dotychczas $w$ literaturze mutację w genie SCL6A8, oraz wykonano spektroskopię rezonansu magnetycznego, która wykazała typowy, nieprawidłowy poziom kreatyny w centralnym ukladzie nerwowym. Pacjentka prezentowała opóźnienie rozwoju mowy oraz rozwoju ruchowego, tagodną niepełnosprawność intelektualną, zaburzenia zachowania oraz napady padaczkowe dobrze kontrolowane kwasem walproinowym.

Rokowanie i stworzenie planu diagnostycznego u pacjentki z deficytem transportera kreatyny stanowi duże wyzwanie kliniczne z uwagi na niewielką ilość danych literaturowych dotyczących pełnej ekspresji tej mutacji u kobiet. Nowe metody terapeutyczne mogą przynieść obiecującą zmianę dotyczącą prognozy dalszego rozwoju i kontroli napadów u osób z deficytem transportera kreatyny obojga płci.

Słowa kluczowe: SCL6A8, deficyt transportera kreatyny, kreatyna, mózgowy deficyt kreatyny, niepełnosprawność intelektualna, padaczka, kobiety

\section{INTRODUCTION}

The inborn cerebral creatine deficiency syndrome is a wide term describing different types of disease which have a common point in abnormalities in creatine level in central nervous system [1]. Creatine and phosphocreatine, its phosphorylated form, is crucial in increasing adenosine triphosphate (ATP) via the creatine kinase reaction [2]. ATP is essential in high levels for muscles, heart and brain to function properly, especially developing ones. In the central nervous system (CNS), the creatine is responsible for many important homeostatic functions, such as controlling calcium ions level and ion gradient restoration, neurotransmitters release and membrane potential maintenance [3-4]. It is possible to define three types of cerebral creatine deficiency syndrome: guanidinoacetate methyltransferase deficiency (GAMT, OMIM \#612736), arginine: glycine amidinotransferase deficiency (AGAT, OMIM \#612718) and creatine transporter deficiency (CRTR, OMIM \#300036) [5]. 
GAMT deficiency is mostly characterised by developmental delay with speech delay and epilepsy, appearing between 3 months and 3 years of age. The patients sometimes also present behavioural problems, such as hyperactivity and autism, or motor disturbances, such as chorea, dystonia or ataxia. In literature, only 110 cases of patients with GAMT are described, while the estimation of occurrence among newborns is 1:250,000 [6-7].

In patients with AGAT deficiency, the epilepsy is not a typical symptom. Most patients present intellectual disability, low muscle strength, hypotonia and behavioural problems. There are only 14 cases of AGAT deficiency reported in literature $[6,8]$.

Creatine transporter deficiency is the most common among the types, with prevalence from $0.3 \%$ to $3.5 \%$ [9]. It is connected to the mutation of SCL6A8 gene (geneID 6535), a member of solute carrier family 6, mapped to Xq28, which is encoding sodium- and chloride-dependent creatine transporter 1 . The mutation can occur de novo $(30 \%)$ or be inherited from maternal side (70\%) [10]. SCL6A8 is expressed in such tissues as skeletal muscles, heart and CNS, however in creatine deficiency syndromes only the CNS seems to be highly affected. The gene normally has a high expression in neurons and oligodendrocytes. It is also expressed in microcapillary endothelial cells, forming the blood-brain-barrier, but not in astrocytes [11-12].

Highly specific sodium- and chloride-dependent creatine transporter 1 consists of 635 amino acids with 12 transmembrane domains. It enables the creatine transport against its concentration gradient, using secondary active transport, via sodium ions gradient $[2,13]$. It is responsible for transporting the creatine produced by kidney and liver and taken from the diet to the CNS and the muscles [14]. A mutation of this transporter can be a common cause of X-linked intellectual disability. Typically, the affected hemizygous males present the symptoms, including developmental delay, especially expressive language delay, epilepsy and autistic behaviour [15]. Some symptoms, such as mild cognitive impairment with learning difficulties and behaviour disorders, were also observed in female carriers, who comprise $0,024 \%$ in the general population. Occasionally, the female carriers also present late onset, sporadic epileptic seizures [16].

The overall image of CRTR in some male adult patients resembled more a progressive disorder. The symptoms included cerebral atrophy or corticobasal dementia combined with gastrointenstinal abnormalities, such as gastric and duodenal ulceration, chronic constipation, ileus, megacolon and intestine perforation, which could indicate visceral and muscular abnormalities [17-18].

Apart from genetic testing, elevated creatine/creatinine urine ratio and low creatine levels in central nervous systems measured by the quantitative proton magnetic resonance spectroscopy (H-MRS) are helpful in diagnosis of CRTR [13]. The creatine uptake can be also measured in fibroblasts and lymphoblasts because of their expression of SLC6A8 gene [2, 18].

A diagnostic marker for CRTR is the urinary creatine/ creatinine ratio, with normal levels between 0.006 and 1.2 in children aged $0-4$ years, between 0.017 and 0.72 for children aged 4-12 years and between 0.011 and 0.24 for older patients. This marker is, however, affected by diet and other individual factors [18-20].

The brain level of creatine is highly reduced in H-MRS testing. Guanidinoacetate (GUAC) in urine and plasma are normal, which helps with differential diagnosis with GAMT [2]. The female carriers do not present unequivocally lower total creatine signal in H-MRS, elevated creatine to creatinine ratio in urine or impaired creatine uptake in fibroblasts, all typical for affected males. H-MRS in female patients show a creatine peak reduced by $13 \%$ to $50 \%$, what sometimes can place them within the range normal in unaffected group. Taking that into consideration, the genetic testing is the primary diagnostic tool for female patients [21-22].

\section{CASE REPORT}

A 4-year-old girl was admitted to Department of Developmental Neurology for a confirmation of diagnostics of cerebral creatine deficiency syndrome, in a diagnostic process of speech and motor delay.

She is a child from the third pregnancy, first labour. Two previous pregnancies ended in miscarriage, respectively in 7 and 11 weeks of gestational age, due to coagulopathy presented by the mother, diagnosed with MTHFR gene mutation. The patient was born in 39. week of gestation, with Apgar score 10/10 and birthweight 3025 grams. No complications occurred during pregnancy or labour. Both of her parents are healthy and unrelated. Her 16-year-old half-sister from paternal side is also healthy. Her mother's brother has hypoacusia, amblyopia and presents speech delay.

She started sitting at 7 months of age and began to make first steps at 16 months. She spoke first words ("mom", "dad") at 1 year of age.

At 20 months of age she received the vaccination containing vaccine against Haemofilus influenzae type b, poliomyelitis, chickenpox and DPT, she developed high fever up to 39 degrees Celcius and presented tonic-clonic febrile seizure. The seizure lasted about 1,5 minute, with subsequent loss of consciousness lasting 1,5 hour.

After two months she presented similar tonic-clonic seizure without fever or symptoms of infection. The seizure occurred in a stressful situation. She was admitted to the local hospital to perform EEG and head CT scan which showed no abnormalities. The third seizure was observed after head injury when the patient fell from a couch and had a morphology similar to previous episodes.

During her neurological examination at 2 years of age, she mainly tiptoed. Her head's circumference was normal $(48 \mathrm{~cm})$ and her weigh was10 kilograms. She still spoke only two basic words, but in her parents' opinion she seemed to understand the verbal commands. She started to take valproic acid (300 mg per day). On a check-up after three months the parents did not report any seizures, even during tonsilitis (without a fever).

The parents did not report any tonic-clonic seizure for a year, despite her having undergone an infection with 
a high fever (39.5 degrees Celsius). They observed, however, short absence episodes lasting up to few seconds. During a follow-up EEG examination the bioelectrical activity was within normal range, with bilateral theta slow waves (single and in series) and delta waves with amplitude slightly higher than the background activity.

She had not improved her gait up until 3 years of age when she started to walk both tiptoeing and heel-to-toe. In an orthopaedic consultation she was diagnosed with restricted mobility in her ankle joints. She also started to present auto aggression and aggression towards guardians: she bit them when she got angry.

In a genetic testing performed in 2018, she was diagnosed with methylenetetrahydrofolate reductase (MTHFR) heterozygotic mutation (MTHFT_C77CT) and plasminogen activator inhibitor 1 (PAI-1) homozygotic mutation (PAI-1 4G). As it did not explain her symptoms, she underwent further genetic testing, with excluded amino acids and organic acids metabolic disorders, fatty acid oxidation disorders, carbohydrates metabolic disorders, storage diseases, immune deficiencies and lipid disorders.

During psychological assessment she was diagnosed with mild intellectual disability. She used only single, shortened or misinterpreted words, with abnormal articulation. She also had difficulties in understanding verbal commands or terms connected with space. She could not understand logic tasks based on finding an object similar to a group or alternating series. The girl also presented small range of transient memory. She had problems with coordination and balance, and needed help with getting dressed. She was impulsive, reacting inadequately with tantrums.

During her check-up in an outpatient clinic she presented elevated creatine kinase level (239 U/l) in her laboratory results. She was then referred for further genetic testing, concentrated on SLC6A8 mutation. In Next Generation Sequencing (NGS) from saliva sample, a heterozygotic mutation in SCL6A8 gene, variant c.1016_1016+8delAGTAAGCAC was observed. This variant was assessed as potentially patogenic. After obtaining the results, both parents underwent NGS testing from blood samples, which turned out negative.

On admission, she presented mixed gait with more tiptoeing than heel-to-toe walking. She started using the endings of words to communicate and, what is more, she used non-verbal communication. She seemed sociable and gladly interacted with both adults and children, but according to the mother's account, she often did not cooperate with teachers and peer group in kindergarten. She had not presented any tonic-clonic seizures nor absence episodes, however she remained treated with valproic acid.

During hospitalisation, the changes in performed EEG were described as slightly abnormal, with theta waves in groups and series located bilaterally, with a voltage higher than background signaling.

As a confirmation of the diagnosis, the girl was referred for the magnetic resonance (MR) with spectroscopy (HMRS). In the MR it was observed that the triangular central body and posterior horn of left lateral ventricle was moderately dilated and posterior part of stem of right lateral ventricle body was slightly dilated. The frontal horns were rounded. The subarachnoid space on frontal and parietal lobes convexity was segmentally moderately dilated, with the predominance of left hemisphere. The splenium and the posterior part of trunk of corpus callosum were hypoplastic. The H-MRS showed that in the white matter of both hemispheres, the level of creatine in comparison to choline is low and stands at 1:3 for both short and long echo time. [Fig. 1-5] The proportion between creatine and choline is also low (1:2) in the right central part of lentiform nucleus. The distribution of metabolites in the white matter confirmed the pathological mutation in SCL6A8 gene, leading to a diagnosis of CRTR. However, due to the lack of seizure combined with no causative therapy being available, no changes were made in medications, with the emphasis on speech therapy.

All figures were prepared via MRI Magnetom Scyra 3 Tesle system, using matrix coil HeadNeck 20ch. Creatine $(\mathrm{Cr})$ signal normally is stable and higher than choline (Cho) signal, however in this case it is 2 to 3 times lower than choline signal. We could not obtain referential electromagnetic spectrum, because in the whole cerebrum the creatine metabolite $(\mathrm{Cr})$ signal was very low, departing from normal values.

\section{DISCUSSION}

The mutation in SCL6A8 in females is still not a well investigated problem. We base our knowledge mostly on single case reports which cannot take into account differences between families, such as other genetic predisposition or therapy methods. While CRTR in males is considered one of the most common etiology of X-linked intellectual disability [23], females are rarely tested for SCL6A8 mutation as they are thought to be non-symptomatic or at least showing only mild symptoms.

Another problem, particularly seen in this case, is the fact that the number of potentially patogenic mutation in one gene is huge and we can always observe novel mutations, with unknown influence on clinical status of the patient. In our case, the mutation was not previously described, despite the fact that the Ensembl data includes 9367 variation in gene, 71 of which are described as connected to X-linked creatine deficiency [24]. Comparing the symptoms of CRTR previously described in literature, such as mild cognitive impairment, learning difficulties and behaviour disorders, with the symptoms presented by our patient, we could have suspected this diagnosis in the girl. However, in a comprehensive view, we encountered also the history of epileptic seizures, which are not presenting symptoms in CRTR in females, and motor delay, which cannot be explained by this mutation. Only after performing H-MRS we could confirm the diagnosis. This imaging, very specific for diagnosing CRTR, proved that the heterozygotic mutation in SCL6A8 gene, variant c.1016_1016+8delAGTAAGCAC, observed in our patient is in fact pathogenic and can be linked with CRTR, also expressed in female patients.

The only bigger paper on female SCL6A8 mutation is based on a German family with CRTR diagnosed in 


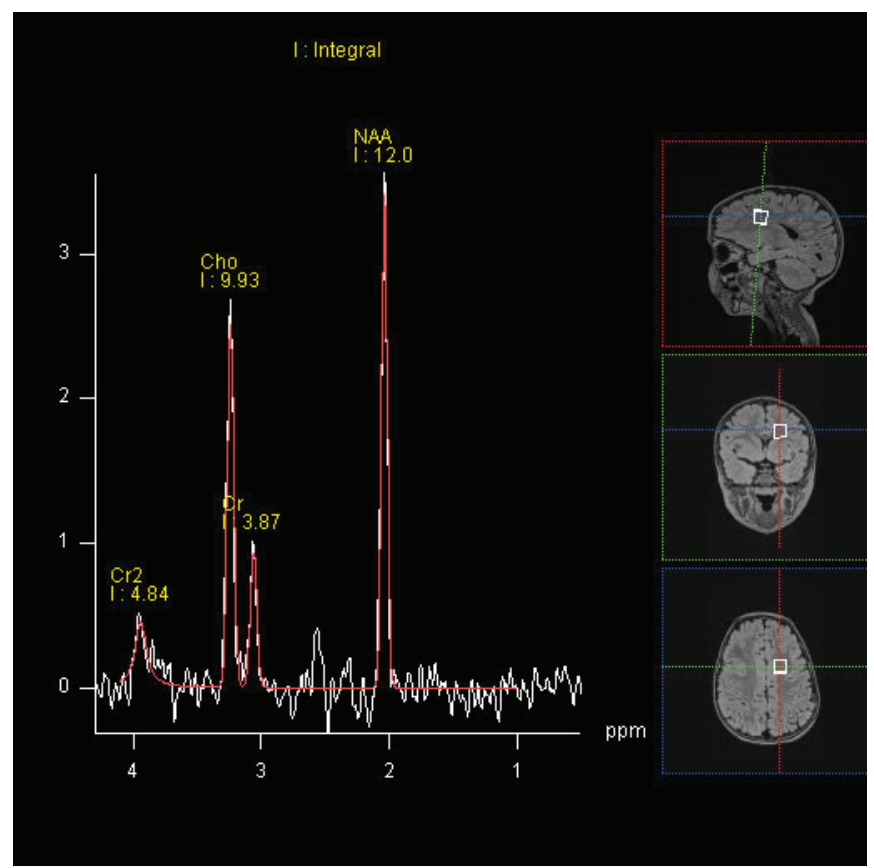

Fig. 1. Magnetic resonance spectroscopy - electromagnetic spectrum: Sequence SVS 90: TR 1570, TE 135ms, NA192 Left hemisphere.

From right to left: $\mathrm{N}$-acetyl-aspartate (NAA) metabolite signal normal, creatine metabolite ( $\mathrm{Cr}$ ) signal very low, choline (Cho) signal normal, creatine metabolite 2 (Cr2) signal relatively low.

Ryc. 1. Spektroskopia rezonansu magnetycznego - widmo: sekwencja SVS 90: TR 1570, TE 135ms, NA192 Lewa pótkula mózgu.

Od prawej do lewej: sygnał metabolitu N-acetyloasparaginianu (NAA) prawidłowy, sygnał metabolitu kreatyny (Cr) znacznie obniżony, sygnał choliny (Cho) prawidłowy, sygnał metabolitu kreatyny 2 (Cr2) stosunkowo niski.

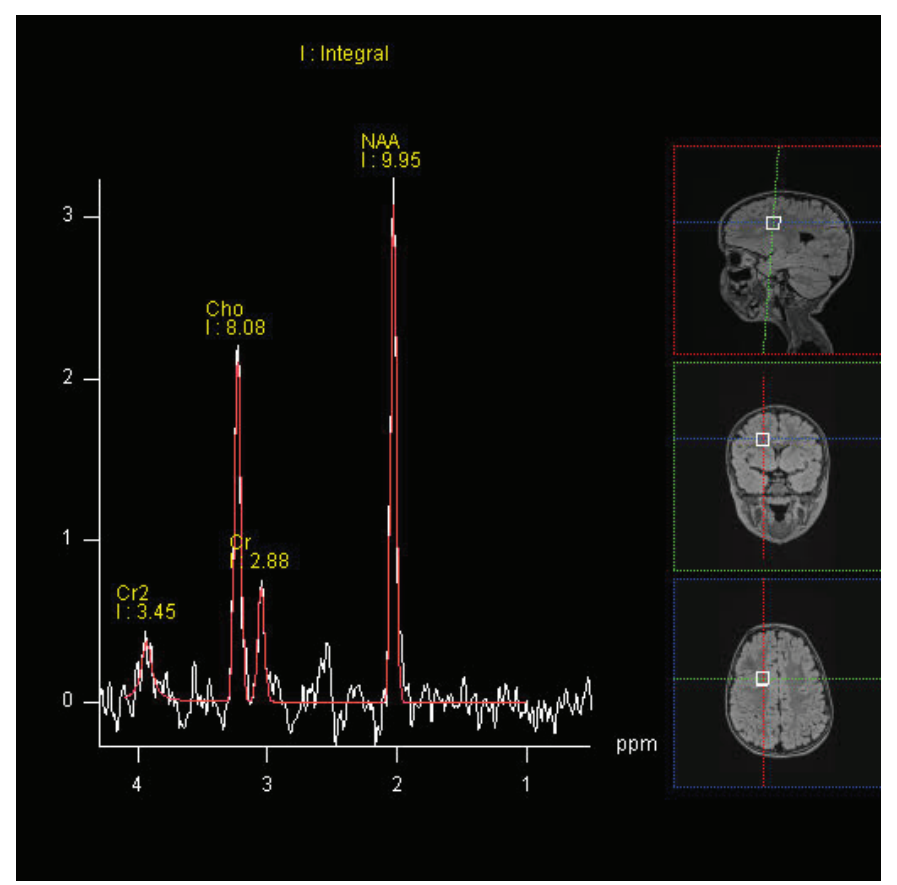

Fig. 2. Magnetic resonance spectroscopy - electromagnetic spectrum: sequence SVS 90: TR 1570, TE 135ms, NA192 Right hemisphere.

From right to left: $\mathrm{N}$-acetyl-aspartate (NAA) metabolite signal normal, creatine metabolite ( $\mathrm{Cr}$ ) signal very low, choline (Cho) signal normal, creatine metabolite 2 ( $\mathrm{Cr} 2$ ) signal relatively low.

Ryc. 2. Spektroskopia rezonansu magnetycznego - widmo: sekwencja SVS 90: TR 1570, TE 135ms, NA192 Prawa pótkula mózgu.

Od prawej do lewej: sygnał metabolitu N-acetyloasparaginianu (NAA) prawidłowy, sygnał metabolitu kreatyny (Cr) znacznie obniżony, sygnał choliny (Cho) prawidłowy, sygnał metabolitu kreatyny 2 (Cr2) stosunkowo niski. 


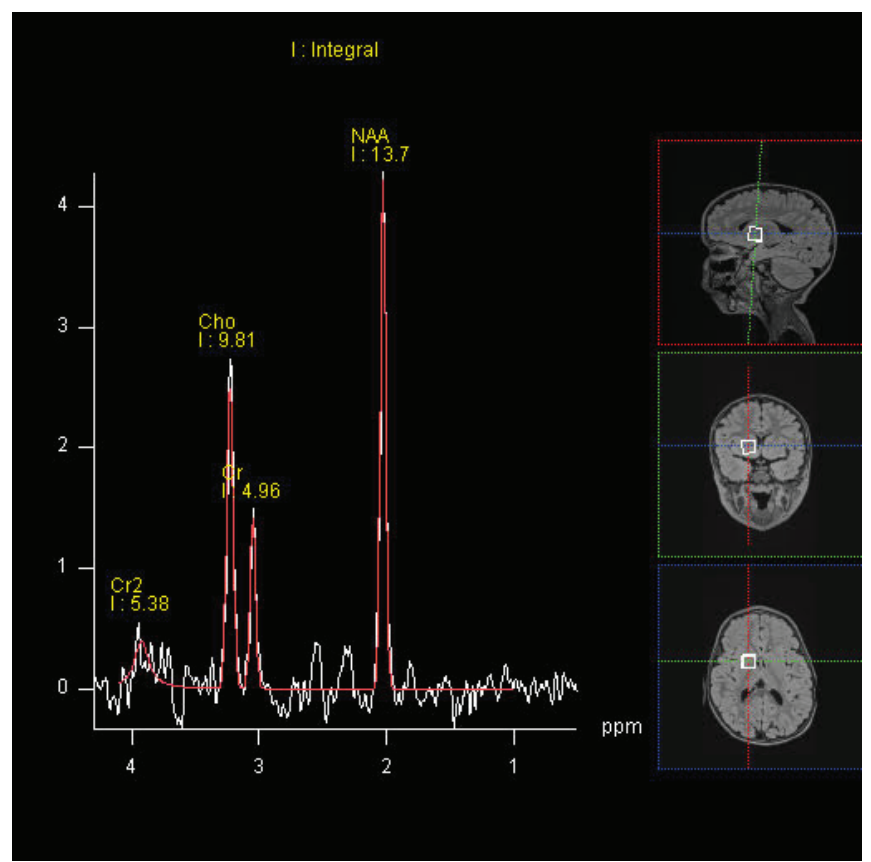

Fig. 3. Magnetic resonance spectroscopy - electromagnetic spectrum: sequence SVS 90: TR 1570, TE 135ms, NA192 Right hemisphere.

From right to left: N-acetyl-aspartate (NAA) metabolite signal normal, creatine metabolite (Cr) signal very low, choline (Cho) signal normal, creatine metabolite 2 (Cr2) signal relatively low.

Ryc. 3. Spektroskopia rezonansu magnetycznego - widmo: sekwencja SVS 90: TR 1570, TE 135ms, NA192

Prawa półkula mózgu.

Od prawej do lewej: sygnał metabolitu N-acetyloasparaginianu (NAA) prawidłowy, sygnał metabolitu kreatyny (Cr) znacznie obniżony, sygnał choliny (Cho) prawidłowy, sygnał metabolitu kreatyny 2 (Cr2) stosunkowo niski.

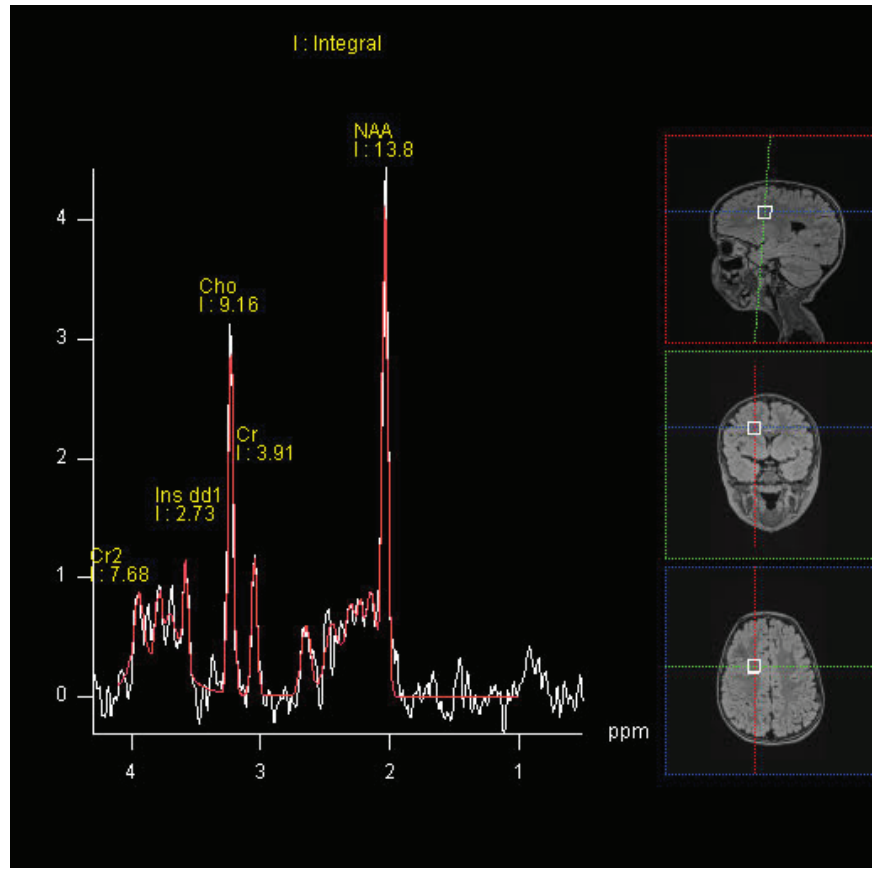

Fig. 4. Magnetic resonance spectroscopy - electromagnetic spectrum: sequence SVS 90: TR 1500, TE 30ms, NA128 Right hemisphere.

From right to left: $\mathrm{N}$-acetyl-aspartate (NAA) metabolite signal normal, creatine metabolite ( $\mathrm{Cr}$ ) signal very low, choline (Cho) signal normal, myoinositol (Ins) signal normal, creatine metabolite 2 (Cr2) signal relatively low.

Ryc. 4. Spektroskopia rezonansu magnetycznego - widmo: sekwencja SVS 90: TR 1500, TE 30ms, NA128

Prawa półkula mózgu.

Od prawej do lewej: sygnał metabolitu N-acetyloasparaginianu (NAA) prawidłowy, sygnał metabolitu kreatyny (Cr) znacznie obniżony, sygnał choliny (Cho) prawidłowy, sygnał mioinozytolu (Ins) prawidłowy, sygnał metabolitu kreatyny 2 (Cr2) stosunkowo niski. 


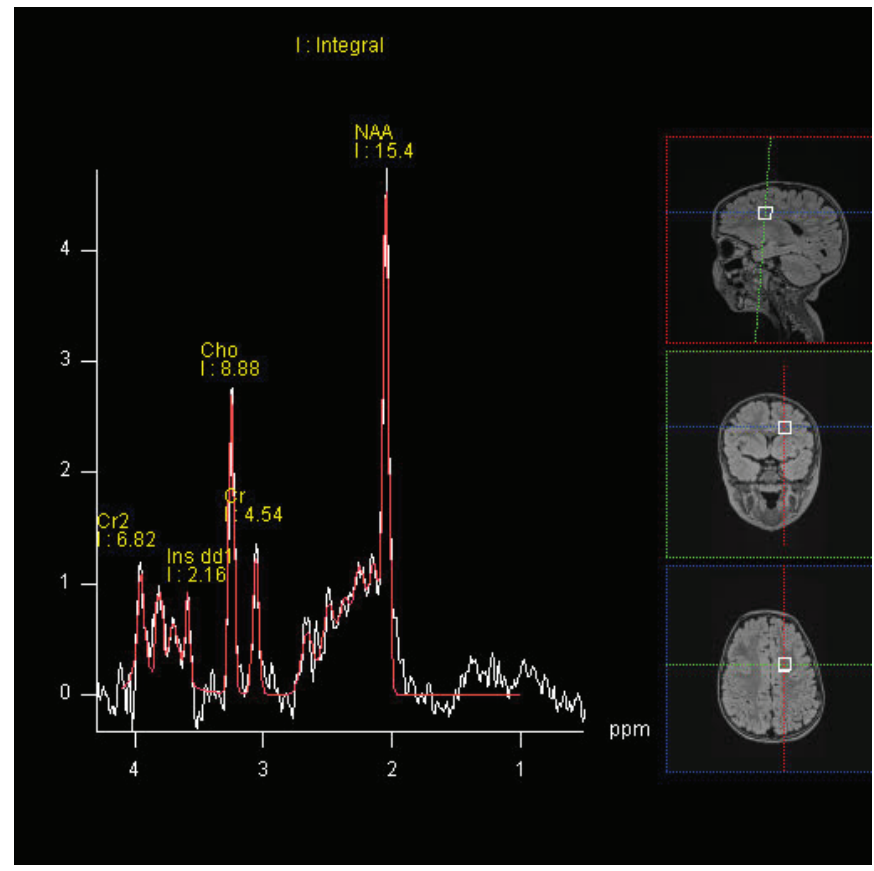

Fig. 5. Magnetic resonance spectroscopy - electromagnetic spectrum: sequence SVS 90: TR 1500, TE 30ms, NA128 Left hemisphere

From right to left: $\mathrm{N}$-acetyl-aspartate (NAA) metabolite signal normal, creatine metabolite (Cr) signal very low, choline (Cho) signal normal, myoinositol (Ins) signal normal, creatine metabolite 2 (Cr2) signal relatively low.

\section{Ryc. 5. Spektroskopia rezonansu magnetycznego - widmo: sekwencja SVS 90: TR 1500, TE 30ms, NA128} Lewa pótkula mózgu.

Od prawej do lewej: sygnat metabolitu N-acetyloasparaginianu (NAA) prawidłowy, sygnał metabolitu kreatyny (Cr) znacznie obniżony, sygnał choliny (Cho) prawidłowy, sygnał mioinozytolu (Ins) prawidłowy, sygnał metabolitu kreatyny 2 (Cr2) stosunkowo niski.

five members, including four women. Among them, one woman presented epilepsy with seizures from 6 to 16 years of life, treated with valproic acid with good results. This woman, along with another one, also presented motor and speech delay. Three women needed special education, while all of them had mild intellectual disability (IQ 50-69). One woman also presented behavioural problems, such as aggression and hyperactivity [21]. This remains consistent with the symptoms presented by the reported patient. The responsiveness to valproic acid was also observed in the reported girl, with a full reduction of epileptic seizures and improvement in EEG after prolonged treatment with valproic acid. What is especially interesting, motor delay is not typically described as a symptom of CRTR, however in this family motor abnormalities were also observed. This may suggest existence of a subtype of CRTR, which is not only connected with speech, but also motor delay. On the other hand, neither of the women presented full spectrum of symptoms of CRTR, which is different to the clinical picture of our patient. The mutation in the family is however different, with missense mutation in SCL6A8 gene (g.G>A, chrX:152959802-152959802, UCSC, hg19, p.Gly351Arg, NP_001136278; p.Gly456Arg, NP 001136277, p.Gly466Arg, NP 005620) rather than deletion, which was described in the reported patient. Among the mutations, previously reported as pathogenic, only two out of seventy one are deletions, none of which was similar to the deletion in our patient.
In comparison to females, a male patient from the German family presented the lowest IQ score, being diagnosed with the moderate intellectual disability, alongside with motor and speech developmental problems and aggression. The level of creatine was reduced in all patients in both gray and white matter, however the reduction was pronounced the most in the affected man, while female patients presented a slighter reduction and their unaffected, heterozygous mother presented a decrease in gray matter, but not in white matter. The researchers observed the correlation between creatine levels in CNS and urinary creatine/ creatinine ratio, but there was no visible correlation between biochemical or spectroscopy results and the degree of intellectual disability [21]. The results in our patient also seem to indicate that there is no direct correlation between the severity or variety of symptoms and the creatine levels in CNS in spectroscopy, as the level was significantly lowered in the white matter of patient's CNS. However, in an animal model of CRTR, it was observed that cognitive defects in mice are connected with lower levels of creatine in hippocampus and cerebral cortex, and the changes could not be prevented or reversed by supplementing creatine in the diet [25-26].

The mutation in SLC6A8 gene can also affect individuals by altered expression of genes responsible for extracellular matrix or cell structure, what can lead to seizure activity, cognitive problems and neurodegeneration [27].

Seizures are not the presenting symptoms in CRTR, 
however the patients often present some form of them, such as myoclonic seizures, partial seizures with secondary generalization, generalized tonic-clonic seizures and convulsive status epilepticus. In most cases they are mild and conventional therapy limits or eliminate them. The first epileptiform activity is observed between 16 months and 12 years of age. EEG can show different abnormalities, such as diffuse slowing, aspecific sharp abnormalities, and focal/ generalized paroxysmal or slow abnormalities, with or without sleep activation, or can be completely normal [18]. This is consistent with the time of appearance and morphology of the seizures in our patient. The girl is also highly responsive to valproic acid, with no seizures presented since the drug was introduced. The EEG, however, was normal at the beginning, and during the therapy presented diffuse slowing, despite neurological improvement of the child.

It is often observed in CT and MR that affected patients present signs of perinatal ischemic insult. It is consistent with the hypothesis of creatine being protective against ischemic episodes [28-29]. There is, however, no sign of ischemic insult in the girl's MR. The major morphological changes observed was hypoplasia of the splenium and the posterior part of trunk of corpus callosum, alongside with dilated ventricular system.

The epileptogenesis can be also connected with the fact that creatine serves also as a neuromodulator. In this situation, the clinical response to treatment does not have to be directly correlated with visible creatine levels upswing in CNS [5, 7].

In $\mathrm{H}-\mathrm{MRS}$, the most visible changes in brain creatine levels $(83 \%$ in gray and $79 \%$ in white matter of agematched normal controls) and creatine/creatinine ratio in urine are observed in the most severe patients. The females show more subtle differences in urine and brain creatinine ( $50 \%$ to $33 \%$ in gray and $45 \%$ to none in white matter) [21-22]. The H-MRS in our patient showed more visible changes in white matter, however the creatine level was also lowered in a part of gray matter, namely lentiform nucleus. Despite different pattern, the changes were still characteristic enough to confirm the diagnosis of CRTR, however we have no information about what could cause this slightly stronger lowering in white matter.

The role of creatine supplementation in CRTR remains unclear, but the majority of patients did not seem to benefit from it. In H-MRS, creatine levels in CNS were not improved in patients with high dosage supplementation in comparison to untreated patients. The neuropsychological status in one female case report has been improved after 12 months of treatment with creatine-monohydrate and creatine precursors, L-arginine and L-glycine, with visible increase in H-MRS. Another single female case report showed the limitation of seizures in a girl with CTRT with refractory seizures. Adding L-arginine or L-glicyne to the creatine supplementation seemed to have beneficial effect on the male therapy as well, with one male patient presenting behavioural improvement after L-arginine co-supplementation. However, the remaining cases showed mild to non-existent clinical improvement and H-MRS did not show improvement in the creatine levels [30].
Some behavioural improvement was also observed in a small group of patients treated with the arginine in monotherapy. Arginine can be transported into the brain cells by the cationic amino acid transporters CAT1 (SLC7A1) and CAT2(B) (SLC7A2) and in this way it should theoretically increase the synthesis of creatine, however the creatine transporter seems to be inevitable for some final parts of synthesis, when it allows intermediate guanidinoacetate metabolite enter the cells [31].

The other suggested pharmacotherapy idea that seems to be effective on rodent model is cyclocreatine, with mice having cognitive defects reversed after 9 weeks of treatment. Cyclocreatine is a creatine analog with a very similar maximum kinetic velocity to creatine, which helps in passive transmembrane transport. It is also susceptible to phosphorylation and desphosphorylation via creatine kinase in mitochondrium and cytosol [32]. In previous research cyclocreatine functioned as a phosphagen in a rodent model. The substance also has an investigated toxicology data in humans due to its usage in a phase I safety study for a new chemotherapeutic drug, where it served as an adjunct [3334]. In rodent model, the mice with knocked out Scl6a8 gene improved cognitively and behaviorally after the cyclocreatine treatment. The cyclocreatine normalised their spatial memory and learning, as well as motor functions and the ability to recognise novel objects after 9 weeks of treatment [12].

A novel idea for CRTR treatment involves the therapy with dodecyl creatine ester, a lipophilic creatine derivative. The substance in in vitro testing on rat cells model penetrated BBB and diffused into neurons. The dodecyl creatine increased also creatine in fibroblasts. On rodent model with mice with knocked-out SCL6A8 gene, the intranasal or intracerebroventricular administration of dodecyl creatine in microemulsion, which prevented degradation of the substance by esterases, led to improvement in novel object recognition [35-36].

There is no consensus on therapy method or prognosis for patients with CRTR. Creating a therapeutic plan is especially hard for female patients with SCL6A8 mutation, as they may present different symptoms with various intensity. What is more, there are few cases reported in literature of female patients presenting fully expressed CRTR. In the case of our patient, we achieved a good control of epileptic seizures with traditional treatment (valproic acid). The speech and behavioural therapy led to improvement in clinical status of the girl. The creatine, arginine or glicyne results in literature did not show effectiveness we would like to achieve in this child, who is slightly improving without such treatment. The novel treatment possibilities are still not introduced in humans and the animal results should be first reproduced on bigger group. None of these treatment methods seem to influence the patients' motor skills, which is also a visible problem in our patient. The girl does not seem to improve significantly from physiotherapy as her gait is still mainly based on tiptoeing, however there is no other possible therapy measures for motor delay in children with CRTR. The question is whether her gait is now more connected with some neuromuscular abnormalities, limiting her ability to walk heel-to-toe, or it is more ha- 
bitual tiptoeing. This is why our patient remains treated only with valproic acid and behavioural and speech therapy with a good control of seizures and slight improvement in speech and behaviour. The physiotherapy should be also continued because of her slight progress and due to possibility of worsening the gait after discontinuation of the therapy.

A bigger study analysing differences in further development, epilepsy control and reaction to different treatment methods in female patients would be beneficial and could encourage physicians to consider testing for CRTR diagnosis not only male, but also female patients with intellectual disability.

\section{BIBLIOGRAPHY}

[1] Schulze A.: Creatine deficiency syndromes. Mol Cell Biochem. 2003 244 (1-2): 143-150.

[2] Salomons G.S., van Dooren S.J.M., Verhoeven N.M. et al.: X-Linked Creatine-Transporter Gene (SLC6A8) Defect: A New Creatine-Deficiency Syndrome. Am J Hum Genet. 2001; 68(6): 1497-1500.

[3] Christie D.L.: Functional insights into the creatine transporter. In: Salomons G.S., Wyss M.: Creatine and Creatine Kinase in Health and Disease. (Subcellular Biochemistry). Springer, Dordrecht 2007; 99-108.

[4] Snow R.J., Murphy R.M.: Creatine and the creatine transporter: A review. Mol Cell Biochem. 2001; 224: 169-181.

[5] Stockler S., Schutz P.W., Salomons G.S.: Cerebral Creatine Deficiency Syndromes: Clinical Aspects, Treatment and Pathophysiology. In: Salomons G.S., Wyss M.: Creatine and Creatine Kinase in Health and Disease. (Subcellular Biochemistry). Springer, Dordrecht 2007; 149-166.

[6] Lemska A., Zawadzka M., Lemka M., et al.: Obraz kliniczny deficytu transportera kreatyny. Opis przypadku. Neurol Dziec 2018; 55: 45-49.

[7] Mercimek-Mahmutoglu S., Pop A. et al.: A pilot study to estimate incidence of guanidinoacetate methyltransferase deficiency in newborns by direct sequencing of the GAMT gene. Gene. 2016; 575(1): 127-131.

[8] Battini R., Leuzzi V., Carducci C. et al.: Creatine depletion in a new case with AGAT deficiency: clinical and genetic study in a large pedigree. Mol Genet Metab. 2002; 77(4): 326-331.

[9] Clark A.J., Rosenberg E.H., Almeida L.S. et al.: X-linked creatine transporter (SLC6A8) mutations in about $1 \%$ of males with mental retardation of unknown etiology. Hum Genet. 2006; 119(6): 604-610.

[10] van de Kamp J.M., Mancini G.M., Salomons G.S.: X-linked creatine transporter deficiency: clinical aspects and pathophysiology. J Inherit Metab Dis. 2014; 37(5): 715-733.

[11] Braissant 0., Henry H., Loup M. et al.: Endogenous synthesis and transport of creatine in the rat brain: an in situ hybridization study. Mol Brain Res. 2001; 86(1-2): 193-201.

[12] Kurosawa Y., DeGrauw T.J., Lindquist D.M. et al.: Cyclocreatine treatment improves cognition in mice with creatine transporter deficiency. $\mathrm{J}$ Clin Invest. 2012; 122(8): 2837-2846.

[13] Wang 0., Yang J., Liu Y. et al.: A novel SLC6A8 mutation associated with intellectual disabilities in a Chinese family exhibiting creatine transporter deficiency: case report. BMC Med Genet. 2018; 19(1): 193.

[14] Brosnan J.T., Brosnan M.E.: Creatine: Endogenous Metabolite, Dietary, and Therapeutic Supplement. Annu Rev Nutr. 2007; 27(1): 241-261.

[15] van de Kamp J.M., Betsalel O.T., Mercimek-Mahmutoglu S. et al.: Phenotype and genotype in 101 males with X-linked creatine transporter deficiency. J Med Genet. 2013; 50(7): 463-472.

[16] DesRoches C.-L., Patel J., Wang P. et al.: Estimated carrier frequency of creatine transporter deficiency in females in the general population using functional characterization of novel missense variants in the SLC6A8 gene. Gene. 2015; 565(2): 187-191.
[17] Kleefstra T., Rosenberg E., Salomons G. et al.: Progressive intestinal, neurological and psychiatric problems in two adult males with cerebral creatine deficiency caused by an SLC6A8 mutation: Letter to the Editor. Clin Genet. 2005; 68(4): 379-381.

[18] Leuzzi V., Alessandri M.G., Casarano M. et al.: Arginine and glycine stimulate creatine synthesis in creatine transporter 1-deficient lymphoblasts. Anal Biochem. 2008; 375(1): 153-155.

[19] Almeida L.S., Verhoeven N.M., Roos B. et al.: Creatine and guanidinoacetate: diagnostic markers for inborn errors in creatine biosynthesis and transport. Mol Genet Metab. 2004; 82(3): 214-219.

[20] Arias A., Corbella M., Fons C. et al.: Creatine transporter deficiency: Prevalence among patients with mental retardation and pitfalls in metabolite screening. Clin Biochem. 2007; 40(16-17): 1328-1331.

[21] Dreha-Kulaczewski S., Kalscheuer V., Tzschach A. et al.: A Novel SLC6A8 Mutation in a Large Family with X-Linked Intellectual Disability: Clinical and Proton Magnetic Resonance Spectroscopy Data of Both Hemizygous Males and Heterozygous Females. In: Zschocke J., Gibson K.M., Brown G., et al.: JIMD Reports - Case and Research Reports, Volume 13. Springer Berlin Heidelberg, Berlin, Heidelberg 2013; 91-99.

[22] Dezortova M., Jiru F., Petrasek J. et al.: 1H MR spectroscopy as a diagnostic tool for cerebral creatine deficiency. Magn Reson Mater Phys Biol Med. 2008; 21(5): 327-332.

[23] Rosenberg E.H., Almeida L.S., Kleefstra T. et al.: High Prevalence of SLC6A8 Deficiency in X-Linked Mental Retardation. Am J Hum Genet. 2004; 75(1): 97-105.

[24] Ensembl: Gene: SLC6A8. Address: http://www.ensembl.org/ Homo_sapiens/Gene/Variation_Gene/Table?g=ENSG00000130821;r $=\mathrm{X}: 153687926-153696588$. Access date: 23.09.2019, at 8.15 PM.

[25] Baroncelli L., Alessandrì M.G., Tola J. et al.: A novel mouse model of creatine transporter deficiency. F1000Research. 2014; 3: 228.

[26] Skelton M.R., Schaefer T.L., Graham D.L. et al.: Creatine Transporter (CrT; Slc6a8) Knockout Mice as a Model of Human CrT Deficiency. Skoulakis EMC, editor. PLoS ONE. 2011; 6(1): e16187.

[27] Nota B., Ndika J.D.T., van de Kamp J.M. et al.: RNA Sequencing of Creatine Transporter (SLC6A8) Deficient Fibroblasts Reveals Impairment of the Extracellular Matrix. Hum Mutat. 2014; 35(9): 1128-1135.

[28] Perasso L., Spallarossa P., Gandolfo C. et al.: Therapeutic Use of Creatine in Brain or Heart Ischemia: Available Data and Future Perspectives: THERAPEUTIC USE OF CREATINE IN BRAIN. Med Res Rev. 2013; 33(2): 336-363.

[29] Kitzenberg D., Colgan S.P., Glover L.E.: Creatine kinase in ischemic and inflammatory disorders. Clin Transl Med. 2016; 5(1): 31.

[30] Dunbar M., Jaggumantri S., Sargent M. et al.: Treatment of X-linked creatine transporter (SLC6A8) deficiency: systematic review of the literature and three new cases. Mol Genet Metab. 2014; 112(4): 259-274.

[31] Braissant 0., Henry H., Béard E. et al.: Creatine deficiency syndromes and the importance of creatine synthesis in the brain. Amino Acids. 2011; 40(5): 1315-1324.

[32] Adriano E., Garbati P., Perasso L. et al.: Electrophysiology and biochemical analysis of cyclocreatine uptake and effect in hippocampal slices. $J$ Integr Neurosci. 2013; 12(02): 285-297.

[33] Schimmel L., Khandekar V.S., Martin K.J. et al.: The synthetic phosphagen cyclocreatine phosphate inhibits the growth of a broad spectrum of solid tumors. Anticancer Res. 1996; 16(1): 375-380.

[34] Teicher B.A., Menon K., Northey D. et al.: Cyclocreatine in cancer chemotherapy. Cancer Chemother Pharmacol. 1995; 35(5): 411-416.

[35] Ullio-Gamboa G., Udobi K.C., Dezard S. et al.: Dodecyl creatine esterloaded nanoemulsion as a promising therapy for creatine transporter deficiency. Nanomed. 2019;14(12): 1579-1593.

[36] Trotier-Faurion A., Passirani C., Béjaud J. et al.: Dodecyl creatine ester and lipid nanocapsule: a double strategy for the treatment of creatine transporter deficiency. Nanomed. 2015; 10(2): 185-191.

\section{Corresponding author:}

Zuzanna Lewandowska,Klinika Neurologii Wieku Rozwojowego, ul. Przybyszewskiego 49, 60-355 Poznań

e-mail: zuzannalewandowska@02.pl 